\title{
18. Impacts of the COVID-19 crisis on vegetable value chains in Ethiopia
}

Seneshaw Tamru, Kalle Hirvonen, and Bart Minten

On March 13, the first COVID-19 case was confirmed in Ethiopia. Three days later, the government closed schools, banned all public gatherings and sporting activities, and recommended social distancing. Other measures to contain the spread of the virus soon followed. Travelers from abroad were put into a 14-day mandatory quarantine, bars were closed until further notice, and travel through land borders was prohibited. Several regional governments banned all public transportation and imposed restrictions on other vehicle movement between cities and rural areas.

While these actions are expected to slow the spread of the disease, they are likely to have substantial effects on food value chains, and thus on the livelihoods of farmers and other workers, and on consumption.

To understand these effects, we conducted a qualitative and rapid appraisal of the vegetable value chain. Building on a large value chain survey that IFPRI undertook in February 2020, we conducted phone interviews (March 23-April 2) with key stakeholders along the vegetable value chain from the main producing areas in the Central Rift Valley to Addis Ababa. Small-scale farmers, large-scale investors, brokers, agro-input dealers, and developmental agents were interviewed. Given that this assessment was based on a limited and nonrepresentative number of interviews, caution is warranted for extrapolation of our observations. They should be seen more as hypotheses of impacts on these value chains. (We intend to substantiate these findings with more representative surveys in the near future.)

\section{Effects downstream and midstream in the vegetable value chain}

1. Vegetable trade and consumption are reduced. There is less trading activity in Addis's vegetable wholesale market (Atkilt Tera) since the start of the COVID-19 crisis, despite this period being the fasting season when vegetable consumption is usually higher. Based on our interviews, this seems to be linked to four factors:

- There is a presumption among some urban residents that consuming raw vegetables increases the likelihood of contracting and spreading the virus, reducing demand for certain vegetables.

- Some - especially larger and wealthier - traders are taking precautionary measures to avoid exposing themselves to the virus. These measures appear to have reduced their vegetable trading activity.

- The travel bans have reduced the volume and frequency of trucks coming to Addis Ababa. 
- Restaurants and other eateries have experienced a slowdown in business, and are opting to reduce vegetable purchases, among other responses.

2. Urban retail prices are not significantly affected so far. Both supply and demand appear to be impacted simultaneously: the lower urban demand that typically leads to a reduction in vegetable prices is balanced by a declining vegetable supply to Addis Ababa.

\section{Effects on farmers}

1. Producer prices for vegetables are on the decline. Fewer traders are traveling to rural areas because of the travel ban, the social distancing policy, and fear of infection. Combined with reduced urban demand and oversupply, producer prices are rapidly declining. For example, a quintal $(100 \mathrm{~kg})$ of head cabbage that sold for about $300 \mathrm{birr}(\$ 9)$ about two weeks earlier sold for only 100 birr (\$3) at the end of March. Similarly, onions that sold for 15-17 birr (\$0.50) per kg about two weeks earlier were selling for about 9-10 birr (\$0.30) per kg at the end of March, a 40\% decline. (A few key informants in these rural areas linked the price declines to a seasonal pattern, however.)

2. Farm losses seem to be increasing. A number of farmers we contacted indicated that they had to leave some vegetables in the field to rot due to the lack of buyers.

3. There is a shortage of farm inputs and their prices are increasing. Prices of important inputs crucial to vegetable production - including fungicides, insecticides, herbicides, fertilizers, and improved seeds - are increasing due to shortages. These seem to be linked to land border closings, which have blocked (sometimes illegal) imports from neighboring countries, and to reduced imports from China.

4. Labor is becoming scarce. Vegetable production is labor intensive and the Central Rift Valley, where most commercial production occurs, usually attracts a large number of daily laborers from across southern Ethiopia. These laborers often gather in set locations in rural towns to be picked up by vegetable producers. However, in response to restrictions on travel and gatherings (informally imposed by the regional police), these workers are increasingly returning to their home areas.

\section{Conclusions and implications}

The COVID-19 pandemic is beginning to disrupt food value chains in Ethiopia and elsewhere, impacting the livelihoods of farmers and the diets of rural and urban households. These effects are likely to hit the poorest and most vulnerable farmers and consumers the hardest, but they are not yet well understood. More evidence is needed to guide the government and other organizations in devising responses. While not representative of the whole value chain, our interviews with vegetable production stakeholders have a number of potential policy implications. 
First, urban demand for fruits and vegetables - high-value, nutritionally rich foods - is declining. It is possible that this is driven by misinformation regarding the risk of contracting COVID-19 from produce. If so, there is a need for widespread and effective information campaigns.

Second, trade is affected by travel bans, as well as reduced competition, because traders are less willing to travel to production areas. Making sure that travel bans do not negatively affect food trade is paramount. To reduce the need for travel, enhanced trading through smartphones, virtual purchasing, and e-payments could be considered so that only truck drivers who pick up loads would need to travel, and traders and brokers would not need to travel.

Third, farmers are apparently hit in two ways. Producer prices are lower, and input prices are up or inputs are not available. Farmers will thus have less incentive to produce these crops, likely leading to lower yields and production in the near future. To avoid further disruptions to the food supply, ensuring the availability of agricultural inputs to farmers at low prices and assuring incentives for production should be a priority for the government in the next few months.

Ethiopia Strategy Support Program senior research fellow Alemayehu Seyoum Taffesse and IFPRI senior technical and policy advisor Anne Bossuyt also contributed to this post.

Originally published April 13, 2020. 